\title{
Non-performing Loans Issues in Malaysian Banking Industry
}

Suhana Mohamed, Mohamad Aqib Abd Hamid, Husnizam Hosin, Mohamad Azwan Md Isa

To Link this Article: http://dx.doi.org/10.6007/IJARBSS/v11-i3/8784 DOI:10.6007/IJARBSS/v11-i3/8784

Received: 31 January 2021, Revised: 27 Febrnuary 2021, Accepted: 08 February 2021

Published Online: 20 March 2021

In-Text Citation: (Mohamed et al., 2021)

To Cite this Article: Mohamed, S., Hamid, M. A. A., Hosin, H., \& Isa, M. A. M. (2021). Non-performing Loans Issues in Malaysian Banking Industry. International Journal of Academic Research in Business and Social Sciences, 11(3), 877-891.

Copyright: (c) 2021 The Author(s)

Published by Human Resource Management Academic Research Society (www.hrmars.com)

This article is published under the Creative Commons Attribution (CC BY 4.0) license. Anyone may reproduce, distribute, translate and create derivative works of this article (for both commercial and non-commercial purposes), subject to full attribution to the original publication and authors. The full terms of this license may be seen at: http://creativecommons.org/licences/by/4.0/legalcode

Vol. 11, No. 3, 2021, Pg. 877 - 891

Full Terms \& Conditions of access and use can be found at http://hrmars.com/index.php/pages/detail/publication-ethics 


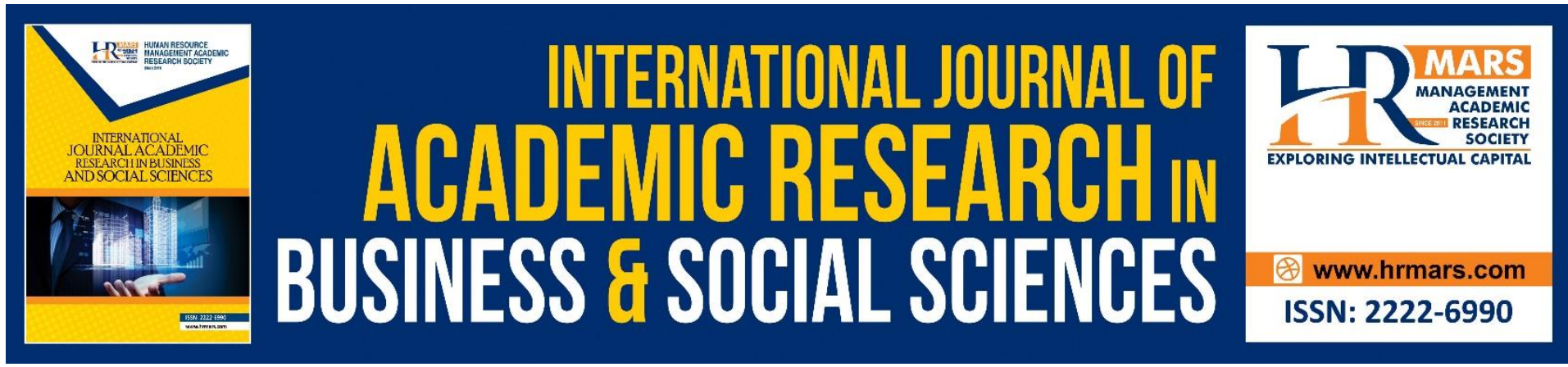

\title{
Non-performing Loans Issues in Malaysian Banking Industry
}

\author{
Suhana Mohamed \\ Department of Finance, Faculty of Business and Management, Universiti Teknologi MARA, \\ Johor Branch, Pasir Gudang Campus, Malaysia \\ Mohamad Aqib Abd Hamid \\ Faculty of Business and Management, Universiti Teknologi MARA, Johor Branch, Pasir \\ Gudang Campus, Malaysia \\ Husnizam Hosin \\ Department of Finance, Faculty of Business and Management, Universiti Teknologi MARA, \\ Johor Branch, Segamat Campus, Malaysia

\section{Mohamad Azwan Md Isa} \\ Department of Finance, Faculty of Business and Management, Universiti Teknologi MARA, \\ Johor Branch, Segamat Campus, Malaysia
}

\begin{abstract}
Around the world, financial institutions face massive risk on non-performing loans. As a result of the previous, financial institutions are obliged to review their lending policies. However, its nonpayment also leads to massive loss on banks in particular and the country in general. Nonperforming credits (NPL) is a prevalent issue that influences budgetary markets dependability as a rule and banking industry suitability specifically. In recent decades, financial crises in various countries have often preceded the rise in non-performing loans (NPLs) in the banks' asset portfolios. The increase in NPLs is an adverse impact on the banking sector. Hence, understanding the determinants of NPLs is crucial to ensure the overall economy's efficiency and soundness. This research studies the factors affecting NPLs in the Malaysian banking industry. Through this research, the researchers can examine the relationships between the dependent variable, NPLs and independent variables, bank interest rate, inflation rate, and unemployment rate. The research uses monthly secondary data from 2015 to 2019, collected from the financial statements and DataStream and applies Descriptive Analysis, Normality Test, Correlation and Multiple Regression Analyses. The results indicate that unemployment and inflation significantly impact and relationship with the NPLs in the Malaysian banking industry. Meanwhile, the interest rate, despite its insignificance, positively affects the NPLs in Malaysia. The findings have important implications on policymaking, besides adding new knowledge to the existing literature.
\end{abstract}


Keywords: Household Debt, Macroeconomic, Determinants, Factors, Financing.

\section{Introduction}

The bank's commercial business will likewise take the stores and loan it to the individual's solicitation to acquire cash. These clients are known as the borrower, and the bank will be a business bank. There are numerous sorts of credit, a few advances are long haul, and some are present. Regardless of what sorts of credit the borrower applies, the credit will be nonproceeding as long as the borrower cannot pay off their advance instalment.

Regularly, the business bank will get the store's benefits when the clients keep or set aside their cash in the bank. Clients who set aside their cash into the financial balance also procure the loan costs indicated by the bank they alluded to (Saini and Sindhu, 2014). When they set aside more cash, they can procure progressively through the bank's loan costs. The business bank will utilize the bank's cash for some loaning exercises and win the financing cost benefits.

The commercial bank goes about as a bank or foundation or an essential part of the events' financial turn (Saini and Sindhu, 2014). The business bank's everyday schedule administrations accept the client's stores, giving credits that are all the more ordinarily for business and some speculation items (Saini and Sindhu, 2014). Other than business areas, business bank additionally serves different divisions, for example, people and government. As indicated by the base standard of Bank Negara Malaysia, the advance delegated nonperforming when the intrigue and chief is the default for six months from the first day of default (Amanda, 2019)

\section{Research Background}

Non-performing credits (NPL) is a prevalent issue that influences budgetary markets dependability as a rule and banking industry suitability specifically. The net non-performing advance (NPL) proportion in the financial framework since the Asian budgetary emergency has bit by bit been in decay from 14.6 percent in December 2008 to 4.8 percent in May 2014 (Santoso, 2015). Government intercession to non-performing credit recuperation techniques has contributed most to the decrease. The Malaysian government and banks have prevailed regarding expelling the non-performing credits (NPL) from banks Accounting report (Santoso, 2015).

The Malaysian government has taken responsive activities to tackle the money-related issues by making the Corporate Debt Restructuring Committee (CRDC), Danamodal, an association for infusing government assets and Danaharta, an association for buying non-performing advances. Moreover, full consideration from banks administrations on the accepted procedures in loaning assets and its continual improvement is required to help Malaysia's developing economy. This essential practice will lessen, if not take out, non-performing credits in the nation (Dahalan, 2016).

Budget summaries are data organized from the financial position and money related execution of a substance. The fiscal reports mean to give data about the money related position, monetary execution and income of the substance that are valuable for clients of budget summaries in dynamic (Dahalan, 2016). One segment in the financial part budget summaries that viewed as significant credits to outsiders. Expanding advance to buyers is a 
type of rivalry among banking organizations in Malaysia. This expansion will likewise influence the expanded danger of awful credit. One measure to decide the danger of awful credit is the Nonperforming Loan (NLP) (Santoso, 2015).

Bank Negara Malaysia guidelines indicate that banks with an NPL proportion of over 5 percent considered experience keeping up business progression. Since 2018, the start of the worldwide budgetary emergency, the degree of NPL has expanded substantially. The quantity of NPLs is relied upon to increment enormously inside the following barely any years, which can influence banks' liquidity and benefit and accordingly make a few difficulties for a nation all in all (Dahalan, 2016).

The paper aims to identify the relationship between the interest rate and non-performing loans in the Malaysia banking sector, identify the relationship between unemployment and non-performing loans in the Malaysia banking sector, and identify the relationship between the inflation rate and non-performing loans in the Malaysia banking sector.

\section{Literature Review}

This section examines the existing studies done by previous researchers and to NPLs in the banking industry. The literature review is presented based on the variables studied in this current paper.

\section{Non-performing Loans (NPLs)}

As indicated by Bank Negara Malaysia's base standard, the advance delegated nonperforming when the intrigue and chief defaulted for six months from the first day of default (Amanda, 2019). Fukuda, Kasuya, and Nakajima (2018) in Malaysian intermediary for nonperforming advances depend on hazard the board credits separated by complete resources. Billings, Gonzalez-Hermosillo, and Pazarbasioglu (1996) did a study uncovers that the proportion of non-performing credit to add up to advance increment the likelihood of banking delicacy it lessens the likelihood of endurance.

\section{Bank Interest Rate}

Bank Interest rate generally can be characterized as the benefit of the bank earned from the clients by obtaining the clients' cash. Aside from the essential bank loan cost, there is likewise progressive accrual forced by the bank to the clients (Amanda, 2019). Besides, the pressure on agents and family units originates from the financing cost gathering in their advances, contract and charge cards (Amanda, 2019).

Investigating the business advance itself is a typical stage for a little organization to siphon in capital into their business to produce benefit and spike organization improvement and development. It is fundamental for a family unit or a shopper to apply for vehicle advances, charge cards, and home loan from banks as this is the right route for them to acquire cash (Bofondi \& Gobbi, 2017). Hypothetically, if the financing costs have diminished, the customers will renegotiate their home to get a lower financing cost on their home loan credit, for increasingly moderate lodging instalment (Durafe, \& Singh, 2016).

Murthy, Mohammed Kamil, Anthony Mariadas, and Devi (2017) investigate the factors influencing non-performing loans, found that bank interest rates significantly and positively 
impacted non-performing loans in commercial banks in the Selangor state of Malaysia. Atem (2017) studied the significant factors affecting non-performing loans of KCB Bank Kenya Limited also found that interest rate positively and significantly affects non-performing loans. Fofack (2005) studied the leading causes of non-performing loans during the economic and banking crises that affected Sub-Saharan Africa countries in the 1990s. He found no significant relationship between the interest rate and non-performing loans in Sub-Saharan Africa.

\section{Unemployment Rate}

Unemployment rate refers to those who are jobless but willing to search for a vocation. The comprehension of unemployment as straightforward as individuals who do not have an occupation. The unemployment rate figured up by the aggregate of jobless divided by the aggregate of the workforce. Messai and Jouini (2013) found a significant and positive relationship between unemployment with non-performing loans. Unemployed clients might not have the capacity and pledge to reimbursing the credits, and henceforth, this prompts the expanding of non-performing loans (Durafe \& Singh, 2016).

The unemployment rate development will impact the customer's acquiring power and limit in money-related duty. Makri, Tsagkanos, Bellas (2014) have recorded a positive connection between credit quality and joblessness, where borrowers' incapacity to pay the advance portion due to the joblessness. It is prominent that the unemployment rate has debilitated borrowers' obligation adjusting limit and make indebted individuals progressively powerless against unfavourable paying off debtors overhauling issues (Bofondi \& Gobbi, 2017).

Klein (2013) studied the NPLs in Central, Eastern and South-Eastern Europe (CESEE) from 1998 to 2011 using a panel VAR method and found a positive relationship between unemployment and NPLs, where the level of NPLs tends to increase when unemployment rises. Warue (2013) investigated the link between NPLs and bank-specific and macroeconomic factors and established how these factors affect NPLs among commercial banks in Kenya. There is a positive relationship between NPLs and the unemployment rate. Vatansever and Hepsen (2015) conducted a study to investigate a significant relationship between macroeconomic indicators, bank-level factors and NPL ratio in Turkey between January 2007 to March 2013. They found a positive effect between the unemployment rate and the NPL ratio. NPL ratio rises as and when the unemployment rate increases.

Kartikasary, Marsintauli, Serlawati, \& Laurens, (2020) conducted a study to examine the factors influencing NPLs in companies listed on the Indonesian Stock Exchange Banking sector with the annual data for the period from the year 2014 to 2017 using the regression method. They found a negative relationship between unemployment and NPLS in the long run and short run, where if there is an increase in the unemployment rate, then there will be a drop in NPL and vice versa.

\section{Inflation Rate}

According to Badar and Yasmin Javid (2013), who assessed long and short-run dynamics between NPLs and macroeconomic variables covering the period from January 2002 till December 2011 of commercial banks in Pakistan, the Johansen and Juselius multivariate cointegration tests show a positive relationship between the NPL and inflation rate in the long-run. The inflation rate is influencing the ability of borrowers to repay their borrowing. 
When the country is experiencing high inflation rate, customers find it difficult to pay their existing loans due to rising cost of capital.

A study conducted by Patricia-Nezianya and Izuchukwu (2014) examined the implication of NPL on economic growth in Nigeria and found that inflation appeared in Ordinary Least Square (OLS) with a positive sign and significant coefficient. They explained that there is a significant relationship between inflation and NPLs. Greenidge and Grosvenor (2009) created several models to forecast NPLs in Barbados' banking sector. They used Autoregressive Integrated Moving Average (ARIMA) forecasting models, they found a positive relationship between inflation and NPL, where a higher inflation rate leads to an economic climate that eventually results in a rise in the level of NPLs. As inflation increases, borrowing costs get more expensive and ultimately worsen the quality of the loan portfolios.

Skarica (2014) examined the determinants of the NPL ratio changes in selected European emerging markets during the third quarter of 2007 until the third quarter of 2012 and found a positive relationship between inflation and NPLs. He concluded that an increase in inflation rates is estimated to cause growth in the NPL ratio. Saba and Kouser (2012) studied the determinants of NPLs in the United States banking sector from 1985 to 2010 and found that the relationship between NPLs and inflation is positive. Rinaldi and Sanchis-arellano (2006) concluded that when the economy slows down, the GDP has a lower increase and the level of NPLs increases. There is a direct connection between the NPLS and the inflation rate.

Shingjergji (2013) researched the impact of macroeconomic variables on NPLs in the Albanian banking system and found that the inflation rate indicates a negative relationship with NPLs. Ekanayake and Azeez (2015) investigated the determinant factors of ex-post credit risk as a proxy variable of NPLs in Sri Lanka's commercial banking sector. They found that the inflation rate negatively impacted NPLs in Sri Lanka's commercial banking sector. The result showed there is a reduction of NPLs if inflation is high in the actual period. Inflation reduces the real value of debt and hence makes debt servicing easier.

Zainol, Nor, Ibrahim, and Daud (2018) studied the macroeconomic factors determining the NPLs of the banking and financial institutions in Malaysia by using quarterly data from 2006 until 2015 Auto-Regressive Distributed Lag (ARDL) method. They found no significant relationship between the inflation rate and NPLs in Malaysia during the period under review.

\section{Theoretical Framework}

Pagano and Jappelli (2014) show that data sharing lessens antagonistic choice by improving banks data using a loan candidate. The lopsided data hypothesis states that it might be hard to recognize financially sound from terrible borrowers (Auronen, 2013), resulting in antagonistic determination and good dangers issues. The hypothesis clarifies that in the market, the gathering with more data on a particular thing to be executed (for this situation the borrower) is in a situation to arrange ideal terms for the exchange than the other party (Auronen, 2015). Unfriendly choice and good perils have prompted noteworthy amassing of non-performing credits in banks (Bester, 2014; Bofondi and Gobbi, 2017).

Figure 1 shows three (3) independent variables: interest rate (INT), unemployment rate (UN) and inflation rate (INF), and Non-performing Loan (NPL) is the dependent variable. 


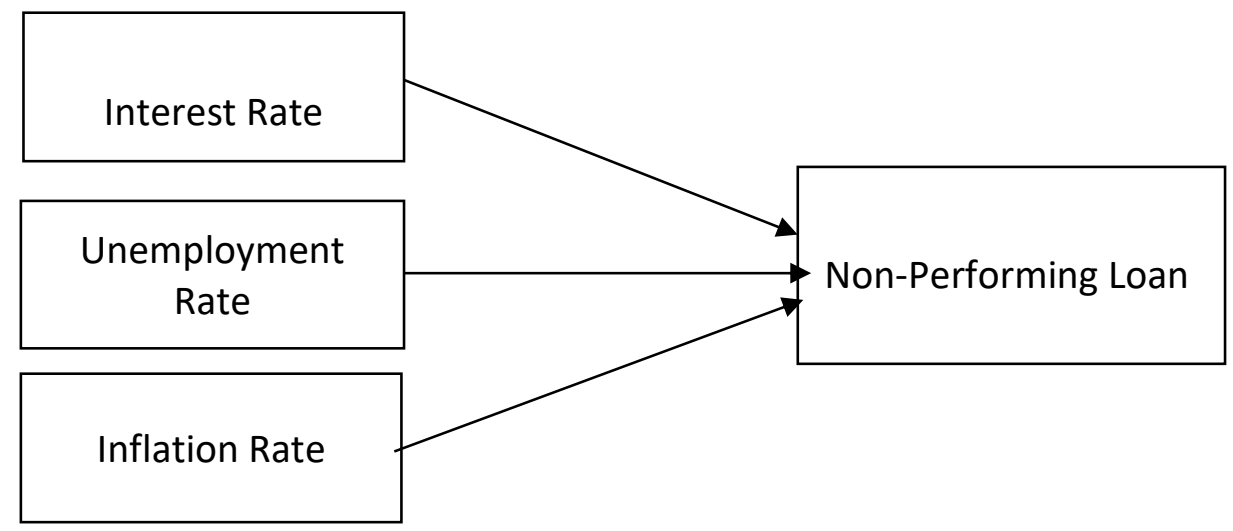

Independent Variable

Dependent Variable

Figure 1. The study's theoretical framework (Bofondi \& Gobbi, 2017; Zakaria et al., 2017; Auronen, 2015, 2013; Bester, 2014; Pagano \& Japelli, 2014).

\section{Research Methodology}

\section{Research Design}

A non-performing loan in which the borrower is in neglects or default to meet its obligation commitments of scheduled payments which past due for more than 365 days. The researchers utilized the audited monthly data collected from 2015 to 2019.

The hypothesis for this study is as follows:

$\mathrm{H}_{0}$ : There is no significant relationship between independent variables (interest rate, unemployment rate, inflation rate) and Non-performing loan in Malaysian Banking Sector

$\mathrm{H}_{1}$ : There is a significant relationship between independent variables (interest rate, unemployment rate, inflation rate) and Non-performing loan in Malaysian Banking Sector

\section{Compulsory Test}

The first compulsory test is the normality test, which determines that either the error term is normally distributed or not. If the $p$-value of Jarque-Bera is more than 5 percent significant level, it concludes that the error term normally distributed.

An autocorrelation test is required to know whether serial independence for the error term existed. Heteroskedasticity is a systematic change in the spread of residuals over the range of measured values.

\section{Data Analysis}

Data analysis is a descriptive analysis that shows the statistic summary of the data set for dependent and independent variables. It measures mean, median, maximum and minimum level, standard deviation and skewers and Kurtosis.

The Augmented Dickey-Fuller test used for the stationary test due to the extensive and complicated set of time series models. The test for stationary is the $p$-value of the ADF 
statistic. If the p-value is below the 5 per cent significance level, then the null hypothesis is rejected and concluded that the data variable is stationary.

Regression analysis used to determine the relationship between the dependent variable and dependent variables. Data used to incorporate with multiple linear regression. The equation as follows:

$$
N P L i=\beta_{0}+\beta_{1} I N T i+\beta_{2} U N i+\beta_{3} I N F i+\varepsilon i
$$

Where:

$$
\begin{array}{ll}
\text { NPL } & =\text { Non-Performing Loan, } \\
\beta_{0} & =\text { Constant } \\
\beta_{1} \text { to } \beta_{3} & =\text { coefficients of variables, } \\
\text { INT } & =\text { interest rate, } \\
\text { UN } & =\text { unemployment } \\
\text { INF } & =\text { inflation rate and } \\
\varepsilon & =\text { error term }
\end{array}
$$

\section{Findings}

\section{Descriptive Analysis}

Table 1. Descriptive Statistic for Factors Affecting Non-Performing Loan in Malaysia

\begin{tabular}{|l|c|c|c|c|}
\hline & NPL & INT & UN & INF \\
\hline Mean & 3.784124 & 3.585000 & 3.336667 & 117.9300 \\
\hline Median & 3.783729 & 3.690000 & 3.300000 & 119.5000 \\
\hline Maximum & 3.829961 & 3.850000 & 3.500000 & 122.3000 \\
\hline Minimum & 3.727180 & 3.350000 & 3.000000 & 109.9000 \\
\hline Std. Dev. & 0.029007 & 0.153628 & 0.119273 & 3.531903 \\
\hline Skewness & -0.209899 & -0.145929 & -0.738220 & -0.581982 \\
\hline Kurtosis & 2.290046 & 1.375239 & 3.565974 & 1.997928 \\
\hline Jarque-Bera & 1.700662 & 6.812574 & 6.250501 & 5.897403 \\
\hline Probability & 0.427273 & 0.033164 & 0.043926 & 0.052408 \\
\hline Sum & 227.0475 & 215.1000 & 200.2000 & 7075.800 \\
\hline Sum Sq. Dev. & 0.049644 & 1.392500 & 0.839333 & 735.9860 \\
\hline
\end{tabular}

Table 1 shows the result of the descriptive analysis. All the NPL, INT, UN, and INF data had reported as a descriptive statistic. From the table above, the mean of NPL, INT, UN and INF are $3.784124,3.585000,3.336667$ and 117. 9300. The median of NPL, INT, UN and INF are $3.783729,3.690000,3.300000$ and 119.5000 . For NPL, its maximum value is 3.829961 , and the minimum value is 3.727180. Overall, NPL has the lowest standard deviation of 0.029007 compared to other variables. Also, NPL, INT, UN and INF's skewness are right-skewed because the skewness is less than zero. The NPL data, INT and INF are less volatile because the Kurtosis is less than 3. Compared to the data, it is more volatile because the Kurtosis is more than 3 , which is 3.565974 . 


\section{Compulsory Test Analysis}

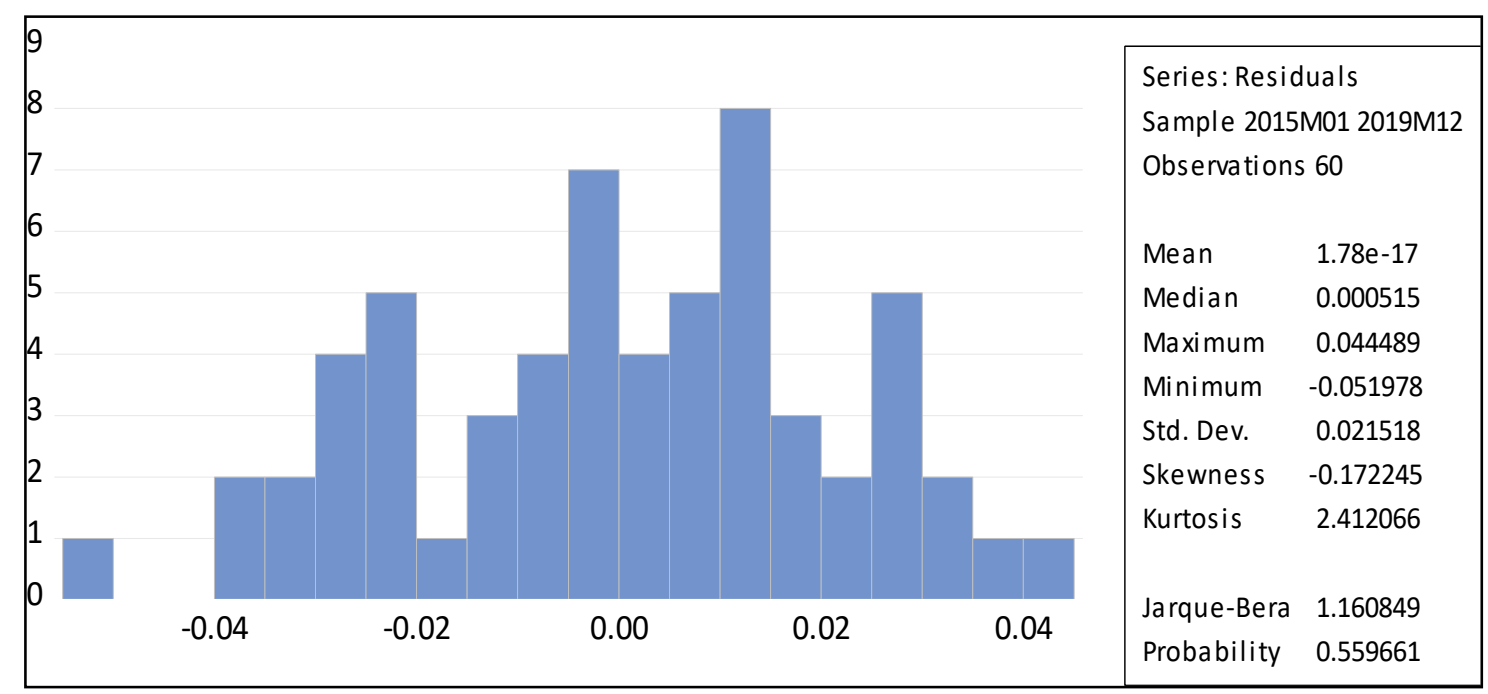

Figure 2: Normality Test

Based on Figure 2, the P-value for the Jarque-Bera Test in Malaysia is 0.559661 . It is greater than the significant level of 0.05 . Hence, this indicates that it fails to reject the null hypothesis and have enough evidence to conclude that the error term normally distributed.

Table 2: Result of Breusch-Godfrey Serial Correlation LM Test Breusch-Godfrey Serial Correlation LM Test

\begin{tabular}{llll}
\hline \hline F-statistic & 44.63419 & Prob. F $(2,54)$ & 0.0000 \\
Obs*R-squared & 37.38510 & Prob. Chi-Square (2) & 0.0000 \\
\hline \hline
\end{tabular}

Based on Table 2 shows that the $p$-value of Chi-square is 0.0000 . It is smaller than the significant level of 0.05 . Hence, this indicates that it can reject the null hypothesis at a $5 \%$ significant level and have enough evidence to conclude that the error term is not serially independent.

Table 3: Result of Heteroscadesticity Test Breusch-Pagan-Godfrey Heteroskedasticity Test Breusch-Pagan-Godfrey

\begin{tabular}{llll}
\hline \hline F-statistic & 2.703778 & Prob. F $(3,56)$ & 0.0540 \\
Obs*R-squared & 7.591171 & Prob. Chi-Square (3) & 0.0553 \\
Scaled explained SS & 4.668822 & Prob Chi-Square (3) & 0.1977 \\
\hline
\end{tabular}

Based on Table 3 shows that the p-value of Chi-Square is 0.0553 . It is greater than the significant level of 0.05 . Hence, this indicates that it fails to reject the null hypothesis and have enough evidence to conclude that the error term is a homoskedasticity problem. 
Table 4: Result of Multicollinearity Test

\begin{tabular}{ccc}
\hline \hline Variable & Centered VIF & Rule of thumb \\
\cline { 2 - 3 } C & NA & $<5$ \\
INT & 1.391471 & $<5$ \\
UN & 1.169329 & $<5$ \\
INF & 1.262207 & $<5$ \\
\hline \hline
\end{tabular}

The centred VIF use to identify if there exists a serious multicollinearity problem. The rule of thumb of VIF is must be below 5 . Based on Table 4, all the values are below 5 , indicating that none of the independent variables shows serious collinearity. Therefore, the t-test and the Ftest used to make inferences on the regression coefficient. In conclusion, there is no multicollinearity exist.

Table 5: Result of RAMSEY

\begin{tabular}{lccc}
\hline \hline & Value & $\mathrm{df}$ & Probability \\
\cline { 2 - 4 } t-statistic & 2.925030 & 55 & 0.0050 \\
F-statistic & 8.555800 & $(1,55)$ & 0.0050 \\
Likelihood ratio & 8.675105 & 1 & 0.0032 \\
\hline \hline
\end{tabular}

Based on Table 5, the p-value of the F-statistic is 0.0050 . It is smaller than the significant level of 0.05 . Hence, this indicates that it can reject the null hypothesis and have enough evidence to conclude that the model is an error in the specification.

Table 6. Results of Unit Root Test

\begin{tabular}{|l|c|c|c|c|}
\hline \multirow{2}{*}{ Variable } & \multicolumn{2}{|c|}{ Level } & \multicolumn{2}{c|}{$1^{\text {st }}$ Different } \\
\cline { 2 - 5 } NPL & No Trend & Trend & No Trend & Trend \\
\hline INT & -1.319864 & -3.361144 & -6.091546 & -6.081214 \\
& $(0.6148)$ & $(0.0672)$ & $(0.0000)^{*}$ & $(0.0000)^{*}$ \\
\hline UN & -1.614030 & -1.680986 & -7.034044 & -6.970001 \\
& $(0.4692)$ & $(0.7473)$ & $(0.0000)^{*}$ & $(0.0000)^{*}$ \\
\hline INF & -2.860768 & -2.738176 & -8.166706 & -8.756233 \\
& $(0.0562)$ & $(0.2258)$ & $(0.0000)^{*}$ & $(0.0000)^{*}$ \\
\hline & -1.878570 & -1.824171 & -7.030945 & -7.346190 \\
& $(0.3400)$ & $(0.6804)$ & $(0.0000)^{*}$ & $(0.0000)^{*}$ \\
\hline
\end{tabular}

* Indicates that the variables are stationary at 5 per cent significance level

In this study, Augmented-Dickey Fuller (ADF) was used to test the unit root test. Table 6 show the result from the unit root test for all variable studied which are non-performing loan (NPL), interest rate (INT), unemployment rate (UN) and inflation rate (INF). The data for the nonperforming loan is stationary at the 1st difference. It shows that the $p$-value for the nonperforming loan is below the significant level at $5 \%$ in the first difference for trend and no trend. It means that the null hypothesis rejected. All independent variables, interest rate, unemployment rate and inflation rate, are stationary at the 1st difference for no trend and trend. All variables were significant at a $5 \%$ significant level at the first difference for no trend 
and trend. The ADF test result, the entire variable in this study is stationary at the level of a significant $5 \%$.

Table 7: Results of Pearson's Correlation Test

\begin{tabular}{|c|c|c|c|c|}
\hline $\begin{array}{c}\text { Correlation } \\
\text { Probability }\end{array}$ & NPL & INT & UN & INF \\
\hline & 1.000000 & & & \\
NPL & ---- & & & \\
\hline & -0.160769 & 1.000000 & & \\
INT & 0.2198 & ---- & & \\
\hline UN & -0.206669 & -0.374619 & 1.000000 & \\
\hline & 0.1131 & 0.0032 & ---- & \\
\hline INF & 0.573804 & -0.451217 & 0.228693 & 1.000000 \\
& 0.0000 & 0.0003 & 0.0788 & ----- \\
\hline
\end{tabular}

Table 7 presents the correlation between the NPL, INT, UN and INF. The $p$-value for the INF is 0.0000 , which is less than 5 percent of the significant level. Therefore, the null hypothesis rejected and show that there is a positive correlation between INF towards NPL. The INT and UN show a negative correlation between INT and the UN toward NPL. Therefore, it fails to reject the null hypothesis, and it shows a negative correlation between INT and the UN toward NPL. Thus, it can conclude that the non-performing loan has a linear relationship or correlation with inflation.

\section{Multiple Regression Analysis}

Table 8. Results of Multiple Regression

\begin{tabular}{|c|c|c|c|}
\hline \multicolumn{4}{|l|}{ Dependent Variable: NPL } \\
\hline Variables & Coefficient & t-statistic & $p$-value \\
\hline Constant & 3.436279 & 18.27936 & 0.0000 \\
\hline INT & 0.000359 & 0.016251 & 0.9871 \\
\hline UN & -0.086579 & -3.321104 & 0.0016 \\
\hline INF & 0.005388 & 5.891057 & 0.0000 \\
\hline & & & \\
\hline R-Squared & Adjusted R-Squared & F-statistic & Prob (F-Statistic) \\
\hline 0.449727 & 0.420248 & 15.25587 & 0.000000 \\
\hline
\end{tabular}

Table 8 summarizes the results of a multiple regression test and the theoretical econometric model shown below.

$$
N P L i=\beta_{0}+\beta_{1} I N T i+\beta_{2} U N i+\beta_{3} I N F i+\varepsilon i
$$

Based on the multiple regression, the econometric equation we rewrite as below:

$$
N P L i=3.436279+0.000359(\text { (INTi) }-0.086579(U N i)+0.005388(I N F i)+\varepsilon i
$$


Table 4 presents the result of the estimated Ordinary Least Squares (OLS) method. This study has found no significant and positive relationship between the interest rate and nonperforming loans in Malaysia. The $p$-value for INT is 0.9871 , which is greater than the 0.05 level of significance, while the coefficient of INT is 0.000359 . The result indicates no significant and positive relationship between the interest rate and non-performing loan at a 5 percent level of significance. Therefore, fail to reject the null hypothesis.

Based on the table, it shows that the $\mathrm{p}$-value for Interest Rate is 0.0 .9871 . It is more than a significant level of 0.05 . Hence, fail to reject the null hypothesis, and there is sufficient evidence to conclude that there is no significant relationship between non-performing loan and the interest rate.

Other than that, the second independent variable used in this study is inflation (IR). The table above shows that unemployment is significant and negatively influenced non-performing loan in Malaysia country. The $p$-value for unemployment is 0.0016 , which is smaller than the 0.05 level of significance. The coefficient of the UN is showing a negative value of -0.086579 . Therefore, the null hypothesis is rejected, indicating a significant and negative relationship between unemployment and non-performing loans at a 5 percent level of significance.

Based on Table 4 shows that the p-value for unemployment is 0.0016 . It is less than the significant level of 0.05 . Hence, reject the null hypothesis, and there is sufficient evidence to conclude a significant relationship between unemployment and non-performing loans.

The third independent variable used in this study is inflation (INF). From the table above, the $\mathrm{p}$-value of INF is 0.0000 smaller than the level of significance while the coefficient for INF is 0.005388; therefore, it indicates that there exists a significant and positive relationship between INF and non-performing loan at a 5 percent level of significance. Thus, the null hypothesis rejected.

Based on Table 4 shows that the $p$-value for inflation is 0.0000 . It is less than the significant level of 0.05 . Hence, reject the null hypothesis, and there is sufficient evidence to conclude a significant relationship between inflation and non-performing loan.

The $p$-value for F-statistic is 0.000000 . It is less than the significant level of 0.05 . Thus, the null hypothesis rejected, and the hypothesis indicates that the model fits at a 5 percent level of significance. Overall, it means that interest rate (INT), unemployment rate (UN) and inflation rate (INF) are fit with the non-performing loan, and it proves a strong relationship between the dependent variables and independent variables.

The value $R^{2}$ obtained is 0.449727 , which means 44.97 percent of the non-performing loan in Malaysia explained by the chosen macroeconomic variables, namely interest rate (INT), unemployment rate (UN) and inflation rate (INF). Other factors determine the remaining 55.03 percent of the variation.

The value of adjusted $R^{2}$ is 0.420248 . This value indicates that 42.02 percent of the nonperforming loan explained by the chosen macroeconomic variables, namely interest rate (INT), unemployment rate (UN) and inflation rate (INF). 


\section{Conclusion}

The findings show that INT has no significant relationship with a non-performing loan at a 5 percent level of significance; thus, it fails to reject the null hypothesis. Therefore, we conclude that there is no significant and negative relationship between the interest rate and nonperforming loan, even the coefficient of interest rate indicates a positive value of 0.000359 . Fofack (2005) also reported the same results regarding the effect of interest rate and nonperforming loan.

According to the findings, this study found a significant relationship between unemployment and non-performing loans at a 5 percent level of significance. Thus, the null hypothesis rejected. The coefficient value of unemployment showed a negative value of -0.086579 ; therefore, there is a significant and negative relationship between unemployment and nonperforming loan. Kartikasary, Marsintauli, Serlawati, \& Laurens (2020) also found the same result.

The discussion in findings shows that INF has a significant relationship with the nonperforming loan at a 5 percent level of significance; thus, reject the null hypothesis. Besides, there is a positive relationship between INF and non-performing loans as the GDP coefficient shows a positive value of 0.005388 . Therefore, we conclude that a significant and positive relationship exists between the inflation rate and non-performing loans. These results are consistent with the study done by Badar \& Yasmin Javid (2013), Fofack (2005), Greenidge \& Grosvenor (2009) and Patricia-Nezianya \& Izuchukwu (2014).

As for recommendations, we suggest the future researcher use other independent variables such as exchange rate, import, export, and real wages. The inclusion of these variables would provide the researcher with a broader-based of understanding.

Future researchers may include different data frequency, such as yearly, quarterly, or weekly. The reason is that the different independent variables might have different sensitivity on a different frequency.

\section{Acknowledgement}

Thanks to all authors for the time, cooperation and commitment in completing the research paper.

\section{Corresponding Author}

Husnizam Hosin.

Department of Finance, Faculty of Business and Management, Universiti Teknologi MARA, Johor Branch, Segamat Campus, Jalan Universiti, 85009 Segamat, Johor, Malaysia.

Email: husni455@uitm.edu.my.

\section{References}

Atem, M. N. C. (2017). Factors Affecting Non-Performing Loans: A case study of KCB Bank Kenya Limited Nairobi Region. Journal of Finance and Economics, 13(3), 1-90.

Amanda (2019). Winter is coming for China's rural banks as overdue loan pressure increases. Retrieved December 16, 2019, from https://www.scmp.com/economy /chinaeconomy/article/3042252/chinas-rural-banks-struggling-under-pressure-overdue-loans 
Aynalem, S. (2018). Factors Affecting Non-Performing Loans in Commercial Bank of Ethiopia. Retrieved August 27, 2018, from https://papers.ssrn.com /sol3/papers.cfm?abstract_id $=3215668$

Badar, M., \& Javid, Y. A. (2013). Impact of macroeconomic forces on non-performing loans: An empirical study of commercial banks in Pakistan. WSEAS Transactions on Business and Economics, 10(1), 40-48.

Bank-specific Factors Affecting Non-performing Loans in Developing Countries: Case Study of Indonesia. (2018, February). Retrieved February, 2018, from http://www.jafeb.org/journal/article.php?code $=61553$

Billings, R., Gonzalez-Hermosillo, B., \& Pazarbasioglu, C. (1996). Banking System Fragility: Likelihood Versus Timing of Failure: An Application to the Mexican Financial Crisis. Working Paper No. 96/142.

Bofondi, M., \& Gobbi, G. (2017). The Big Promise of Fintech. European Economic Review, 2(107), 10-14.

Durafe, A., \& Singh, M. (2016). Cyclical Behavior of Public and Private Sector Banks: A Comparative Study of Non-performing Assets. Journal of Business and Management Research, 1(1), 14-25. https://doi.org/10.3126/jbmr.v1i1.14548

Ekanayake, N., \& Azeez, A. A. (2015). Determinants of Non-Performing Loans in Licensed Commercial Banks : Evidence from Sri Lanka. Asian Economic and Financial Review, 5(6), 868-882. https://doi.org/10.18488/journal.aefr/2015.5.6/102.6.868.882

Fofack, H. (2005). Non-Performing Loans in Sub-Saharan Africa: Causal Analysis and Macroeconomic Implications. World Bank Policy Research Working Paper, 1-36.

Greenidge, K., \& Grosvenor, T. (2009). Forecasting Non-Performing Loans in Barbados. Annual Review Seminar Research Department Central Bank of Barbados, 1(246).

Kartikasary, M., Marsintauli, F., Serlawati, E., \& Laurens, S. (2020). Factors affecting the nonperforming loans in Indonesia. Accounting, 6(2), 97-106.

Klein, N. (2013). Non-Performing Loans in CESEE: Determinants and Impact on Macroeconomic Performance. IMF Working Papers, 13(72), 1.

Makri, V., Tsagkanos, A., \& Bellas, A. (2014). Determinants of Non-Performing Loans: The case of Eurozone. Panoeconomicus, 61(2), 193-206. https://doi.org/10.2298/PAN1402193M

Messai, A. S., \& Jouini, F. (2013). Micro and Macro Determinants of Non-Performing Loans. International Journal of Economics and Financial Issues, 3(4), 852-860.

Murthy, U., Kamil, M. N., Mariadas, A. P., \& Devi, D. (2017). Factors Influencing NonPerforming Loans in Commercial Banks: The Case of Banks in Selangor. International Journal of Business and Management, 12(2), 246.

Patricia-Nezianya, N., \& Izuchukwu, D. (2014). The Implications of Non Performing Loans on Nigerian Economic Growth (1992-2009). IOSR Journal of Business and Management, 16(2), 06-11.

Rinaldi, L., \& Sanchis-arellano, A. (2006). What Explains Household Non-Performing Loans? Working Paper Series, 570, 45. Retrieved from http://ssrn.com/abstract_id=872528

Saba, I., \& Kouser, R. (2012). Determinants of Non Performing Loans: Case of US Banking Sector. The Romanian Economic Journal, XV(44), 125-136.

Saini, P., \& Sindhu, J. (2014). Role of Commercial Bank in the Economic Development of India. International Journal of Engineering and Management Research, 4(1), 27-31.

Santoso, T. I. (2015). "Non performing loan: impact of Internal and external factor evidence in Indonesia". International Journal of Humanities and Social Science Invention, 4(1), 8791, 2015 
Shingjergji, A., \& Shingjergji, I. (2013). An Analysis of the Non-performing Loans in the Albanian Banking System. International Journal of Business and Commerce, 2(6), 1-11.

Skarica, B. (2014). Determinants of non-performing loans in Central and Eastern European countries. Financial Theory and Practice, 38(1), 37-59.

Vatansever, M., \& Hepsen, A. (2015). Determining Impacts on Non-Performing Loan Ratio in Turkey. Journal of Applied Finance and Banking, 5(1), 1-11.

Warue, B. N. (2013). The Effects of Bank Specific and Macroeconomic Factors on Nonperforming Loans in Commercial Banks in Kenya: A Comparative Panel Data Analysis. Advances in Management \& Applied Economics, vol 3(2), 135-164.

Zainol, J. M., Nor, A. M., Ibrahim, S. N., \& Daud, S. (2018). Macroeconomics Determinants of Non-Performing Loans in Malaysia: An ARDL Approach. International Journal of Academic Research in Business and Social Sciences, 8(10), 692-706. 